Creative Commons User License: CC BY-NC-ND

Abstracted by: EBSCOhost, Electronic Journals Service (EJS),

Google Scholar, Journal Seek, Scientific Commons,

Food and Agricultural Organization (FAO), CABI and Scopus

http://eoi.citefactor.org/10.11226/v25i4
Journal of Agricultural Extension

Vol. 25 (4) October, 2021

ISSN(e): 24086851; ISSN(Print); 1119944X

http://journal.aesonnigeria.org

http://www.ajol.info/index.php/jae

Email: editorinchief@aesonnigeria.org

\title{
Effectiveness of Climate Change Adaptation Measures used by Women Garden Egg Farmers in Enugu State, Nigeria
}

https://dx.doi.org/10.4314/jae.v25i4.6

\section{Nnadi, Onyinyechi. I.}

Department of Agricultural Extension, University of Nigeria Nsukka Enugu State, Nigeria

Email: onyinyechi.ogbonna@unn.edu.ng. Phone number: 08061591391

\section{Ogbodo Francisca .N.}

Department of Agricultural Extension, University of Nigeria Nsukka Enugu State, Nigeria Email: francisca.ndidiamaka@yahoo.com. Phone number: 08065094069

Ohagwu. Amara . V.

Department of Agricultural Extension, University of Nigeria Nsukka Enugu State, Nigeria Email: violey.ohagwu@unn.edu.ng; Phone number: 08134960506

\section{Onyia, Chukwuemeka. C.}

Department of Agricultural Economics, University of Nigeria, Nsukka

Email: chukwuemeka.onyia@unn.edu.ng.Phone number: 07030852594

\section{Nnadi Uchenna. V.}

Department of Agricultural Extension, University of Nigeria Nsukka Enugu State, Nigeria Email:uchennamnndi@gmail.com; Phone number: 07030289486

\section{Ozioko, Remigius. I.}

Department of Agricultural Extension, University of Nigeria Nsukka Enugu State, Nigeria Email: remigius.ozioko@unn.edu.ng. Phone number: 07038845649

\section{Abstract}

This study investigated the effectiveness of climate change adaptation measures used by women in garden egg production in Enugu State, Nigeria. Multistage sampling procedure was used to select eighty respondents for the study. Data were collected through the use of semi-structured interview schedule and analysed with descriptive statistical tools such as frequency count, percentage, mean scores and standard deviation. The major effects of climate change on garden egg production were scarcity of floral resources ( $\bar{x}$ $=3.00$ ), increased spread of pests and pathogens $(\bar{x}=2.78)$, reduced pollen production in flowers $(\bar{x}=2.68)$, increased garden egg susceptibility to pathogens $(\bar{x}=2.67)$ and decreased quantity and quality of garden egg production $(\bar{x}=2.67)$. The effectiveness of adaptation strategies used by women in garden egg production were change of farming sites $(\bar{x}=2.97)$, establishment of water reserve and farming close to irrigated area ( $\bar{x}=2.92)$. The identified constraints to adapting to the present climate change scenario included: unstable weather $(\bar{x}=3.00)$, unavailability of modern harvesting techniques $(\bar{x}=2.75)$, increased pest and disease pathogens $(\bar{x}=2.68)$ and 
Creative Commons User License: CC BY-NC-ND

Abstracted by: EBSCOhost, Electronic Journals Service (EJS),

Google Scholar, Journal Seek, Scientific Commons,

Food and Agricultural Organization (FAO), CABI and Scopus

http://eoi.citefactor.org/10.11226/v25i4
Journal of Agricultural Extension

Vol. 25 (4) October, 2021

ISSN(e): 24086851; ISSN(Print); 1119944X

http://journal.aesonnigeria.org

http://www.ajol.info/index.php/jae

Email: editorinchief@aesonnigeria.org

poor access to materials and equipment ( $\bar{x}=2.63)$. Hence, this study recommends provision of incentives such as materials and equipment's and increased training of garden egg farmers on how to reduce and prevent pests and diseases outbreak.

Keywords: Climate change, adaptation measures, garden egg farmers, women

\section{Introduction}

Climate change increasingly affects the lives of many people, especially those of the poor in developing countries. Gender disparities seriously undermine the potential of women as drivers of agricultural growth in Nigeria, considering the population of women engaged in farming (Ugwuja \& Nweze, 2018). Unfortunately, existing gender differences, roles and inequalities increase the impacts of climate change on farmers due to inequalities in access and right to resources (Nnadi, Liwenga, Lyimo and Madukwe, 2019). For instance, it has been noted that some chronically poor women farmers are affected more negatively by climate change and seasonal changes than the men in Africa (Nkengla-Asi, Babu, Kirscht, Apfelbacher, Hanna and Tegbaru, 2017). Vegetable production is known to be sensitive to extreme weather condition, such as low soil moisture and high temperature which are responsible for its low yield (Williams et al. 2018). The influence of increased temperature and rainfall uncertainties on different growth phases of vegetable development from vegetative growth to fruiting can alter the normal development, growth of plant, crop productivity and the economic return of farmers (Fadairo, Williams, Faridah, \& Nalwanga, 2020). Vegetable production faces numerous challenges besides environmental stresses such as prolonged dry spells (Williams et al. 2018). In the wake of deepened situations of climate change, understanding the emerging socio-economic and livelihood consequences of climate on local farmers whose livelihoods are mainly dependent on vegetable cropping is a critical step towards building appropriate adaptation and resilience strategies (Fadairo et al., 2020). Climate change have negative impact on agricultural production in Nigeria, with production losses and increase in crop prices, higher food dependency on foreign imports and Gross Domestic Product (GDP) losses (Bosello, Campagnolo, Cervigni, \& Eboli, 2018). There are gender variations in the ability of farmers to cope and/or adapt to climate change impacts. Men and women farmers are faced with diverse opportunities, knowledge, skill and access to adaptation options.

Women make essential contributions to the agricultural and rural economies globally and in all developing countries. Women make up about 20 percent of the agricultural labour force in Latin America and up to 60 percent in Southern Asia and SubSaharan Africa (International Labour Organisation, 2016; Palacios-Lopez, Christiaensen, \& Kilic, 2017). Recent statistics show that on average, 43 percent of the agricultural labor force is made up of women, and in the least developed countries, two in three women are employed in farming (CGIAR, 2021). Rural women work from dawn to dusk involving themselves in variety of tasks to support their 
Creative Commons User License: CC BY-NC-ND

Abstracted by: EBSCOhost, Electronic Journals Service (EJS), Google Scholar, Journal Seek, Scientific Commons,

Food and Agricultural Organization (FAO), CABI and Scopus

http://eoi.citefactor.org/10.11226/v25i4
Journal of Agricultural Extension

Vol. 25 (4) October, 2021

ISSN(e): 24086851; ISSN(Print); 1119944X

http://journal.aesonnigeria.org

http://www.ajol.info/index.php/iae

Email: editorinchief@aesonnigeria.org

families through their participation in production of major cash and food crops, particularly in cotton, rice, pulses and vegetables (Nifeipiri, Nlerum, \& Isife, 2020). Women and men have different preferences for crops and other agricultural activities as men tend to prefer crop characteristics that will increase market value such as yield, appearance and market demand, while women prefer varieties that are more nutritious, better tasting and easier to cook (Nyasimi \& Huyer, 2017). Women are major producers of garden egg, spinach, pumpkin and other vegetable crops. Vegetables are an essential source of human nutrition and are now globally recognised for nutrition security giving its richness in micronutrient contents and improved awareness on healthy eating among people in recent times (Fadairo, et al., 2020). Garden egg is among the oldest vegetables and indigenous tropical African crops grown in Nigeria with various varieties of economic importance commonly produced in Southeastern Nigeria (Lawal, Barau \& Umoru, 2020) and Enugu State in particular. Garden egg (Solanum Mélongena) is an economic flowering plant, belongs to the family Solanaceae whose members are mostly herbaceous plant, with berry fruit, large endosperm seeds and grown mainly for food and medicinal purposes (Lawal et al, 2020). Nutritionally garden egg contains water $(92.5 \%)$, protein $(1 \%)$, fat $(0.5 \%)$ and carbohydrates $(6 \%)$. Climate change affects agricultural production of farmers, especially the women in Africa as well as Nigeria (Nnadi, et al, 2019) and garden egg farmers. Climate change aggravates the already existing problems faced by women whose livelihood depends on agriculture and access to natural resources, hence adaptation is very pertinent.

Climate adaptation is described as appropriate adjustments to climate variability and change, especially for peasant farmers to enhance resilience or reduce vulnerability to its effects. Adaptation to climate change is considered key in combating climate change in addition to mitigation measures throughout the world (Shrestha, Raut, Maung, Swe, \& Tieng, 2018). As adaptation to climate change impacts is the major development agenda in many developing countries, it is very crucial to have really applicable practices in the field as diverse strategies were reported in adapting to water scarcity and declining soil productivity in agriculture, such as water pumping, animal manure application, compost making and application, crop rotation and crop residues retention (Shrestha et al., 2018).

Adjustment on cropping calendar has been observed particularly on planting and harvesting time based on the start of rainy season (Arunrat et al., 2017). Adaptation strategies are gendered, with men mostly resorting to on-farm agronomic practices such as the use of inorganic fertilizers and also moving into new cash crops while female farmers also use similar on-farm agronomic practices particularly inorganic fertilizers to boost crop production but most importantly resort to petty trading in agricultural and consumable goods, an off-farm strategy (Wrigley-Asante, Owusu, Egyir, \& Owiyo, 2019). Similarly, gender differences in adaptation strategies also exist as traditional gender roles, that are often deeply entrenched, can prevent women from engaging in adaptive strategies in the face of climate change (Nyasimi 
Creative Commons User License: CC BY-NC-ND

Abstracted by: EBSCOhost, Electronic Journals Service (EJS),

Google Scholar, Journal Seek, Scientific Commons,

Food and Agricultural Organization (FAO), CABI and Scopus

http://eoi.citefactor.org/10.11226/v25i4
Journal of Agricultural Extension

Vol. 25 (4) October, 2021

ISSN(e): 24086851; ISSN(Print); 1119944X

http://journal.aesonnigeria.org

http://www.ajol.info/index.php/iae

Email: editorinchief@aesonnigeria.org

\& Huyer, 2017). This makes it imperative to look at climate change adaptation measures used by vegetable (garden egg) farmers. Existing studies (Jamin, Odoemenam, \& Godson-lbeji, 2019; Fadairo et al., 2020; Eze, 2017) examined adaptation measures of farmers but there is gap in knowledge on the adaptation measures used by women farmers in garden egg production in Nigeria even though they are yet to use many of the adaptation measure like other farmers. Many researchers (Eze, 2017; Fadairo et al., 2020; Jamin et al., 2019) studied the indigenous adaptation measures of farmers in Nigeria but most researchers did not show the existing adaptation measures of women farmers and women garden egg farmers. Hence this study assessed climate change adaptation measures used by women garden egg farmers in Enugu State. Specifically, the study sought to examine the effects of climate change on women garden egg production in the State, the adaptation strategies used by the women and the constraints to adapt to climate change.

\section{Methodology}

The study was carried out in Enugu state, Nigeria. Women garden egg farmers in Enugu State constituted the population for the study. Multistage sampling procedure was used in the selection of the respondents. In stage one, two local government areas (Nsukka and Uzo-Uwani) were selected for the study. The criteria used for selection were based on the prevalence of women garden egg farmers and availability of garden egg producers in the area. In the second stage, two towns/communities: Ede-oballa and Nguru as well as Adani and Opanda were selected using purposive sampling technique from the two local governments based on the existence of women garden egg farmers. In the third stage two villages from the four towns/communities were selected which were: Amezi and Umuezioyima as well as Ejuona and Umumgbala in Ede-oballa and Nguru, respectively while Ezikolo and Ejona as well as Ekwuru and Enugu-Nimbo in Abbi and Nimbo respectively. Finally, ten women farmers were selected from each of the villages using snowball sampling technique, making a total of eighty respondents. Quantitative data were gathered using interview schedule to elicit information on respondents' perception of effects of climate change in the area; adaptation measures utilised by the women farmers and the constraints to adaptation of the women farmers.

To obtain information on the effects of climate change on garden egg production, respondents were requested to indicate the effects of climate change on garden egg production on a four-point Likert-type scale of very great extent (3), great extent (2), little extent (1) and no extent (0). The weighted values were summed up to give 6 and divided by 4 , giving a mean value of 1.5 . Items with measures of $\geq 1.5$ were considered as having effects. To measure the level of effectiveness of climate change adaptation strategies used, respondents indicated whether the strategies were; very effective (3), effective (2) slightly effective (1) and not effective (0). The 
Creative Commons User License: CC BY-NC-ND

Abstracted by: EBSCOhost, Electronic Journals Service (EJS),

Google Scholar, Journal Seek, Scientific Commons,

Food and Agricultural Organization (FAO), CABI and Scopus

http://eoi.citefactor.org/10.11226/v25i4
Journal of Agricultural Extension

Vol. 25 (4) October, 2021

ISSN(e): 24086851; ISSN(Print); 1119944X

http://journal.aesonnigeria.org

http://www.ajol.info/index.php/jae

Email: editorinchief@aesonnigeria.org

weighted values were summed up to 6 and gave a mean value of 1.5 . Items with measures of $\geq 1.5$ were considered effective and $<1.5$ were regarded as not effective. To identify constraints to adaptation to climate change, respondents reacted to a four-point Likert-type scale of very great extent (3), great extent (2), little extent (1) and no extent (0) to indicate the problems faced in adapting to climate change. Items with measures of $\geq 1.5$ were considered as having constraints and < 1.5 were regarded as having no constraints. Data were analysed with descriptive statistical tools such as frequency count, percentages, mean scores and standard deviation.

\section{Results and Discussion}

\section{Effects of Climate Change on Garden Egg Production}

Data in Table 1 show that the major effects of climate change on garden egg production included scarcity of adequate floral resources $(\bar{x}=3.00)$, increased spread of pests and pathogens $\left(\bar{x}_{=}=2.78\right)$ and reduced pollen production in flowers $\left(\bar{x}_{2}=2.68\right)$. The results show that climate change affect garden egg production. This agrees with Seo and Mendelsohn (2018) that the adverse effects of global climatic change evidenced in the form of drought, temperature variations, rainfall fluctuations and wind speed affect flowering vegetation including crops. The result largely agrees with Bisbis, Gruda and Blanke (2018) that climate change impacts on the production, physiology, yield, and product quality of vegetables is affected by precipitation and temperature conditions, as well as subjected to extreme weather events. It influences flower development, increases the spread of diseases, and pests' activity development. In agreement to this, Bisbis et al (2018), noted that heat stress reduces fruit set of fruiting vegetables, speeds up development of determinate vegetables, shortening their time for photo-assimilation, causes yield losses with an impaired product quality, thereby increasing production waste. The standard deviation of the variables was less than one, showing that the individual responses do not vary much from the mean; hence the respondents have similar opinions as regards effects of climate change in garden egg production. 
Creative Commons User License: CC BY-NC-ND

Abstracted by: EBSCOhost, Electronic Journals Service (EJS),

Google Scholar, Journal Seek, Scientific Commons,

Food and Agricultural Organization (FAO), CABI and Scopus

http://eoi.citefactor.org/10.11226/v25i4
Journal of Agricultural Extension

Vol. 25 (4) October, 2021

ISSN(e): 24086851; ISSN(Print); 1119944X

http://journal.aesonnigeria.org

http://www.ajol.info/index.php/jae

Email: editorinchief@aesonnigeria.org

Table 1: Effect of climate change on garden egg production

\begin{tabular}{lll}
\hline Perceived effects & Mean & $\begin{array}{l}\text { Standard } \\
\text { Deviation }\end{array}$ \\
\hline Scarcity of adequate floral resources & $3.00^{\star}$ & 0.000 \\
Increased spread of pests and pathogens & $2.78^{*}$ & 0.415 \\
Reduced pollen production in flowers & $2.68^{*}$ & 0.567 \\
Reduced garden egg behaviour and distribution activities & $2.67^{\star}$ & 0.572 \\
Increased garden egg susceptibility to pathogens & $2.67^{*}$ & 0.475 \\
Decreased quantity and quality of garden egg production & $2.67^{*}$ & 0.542 \\
Changing the dates and patterns of flowering & $2.62^{*}$ & 0.715 \\
Reduced fruit productivity & $2.57^{*}$ & 0.767 \\
Shortening the plant lifespan. & $2.43^{*}$ & 0.698 \\
Prolonged production period & $2.30^{*}$ & 0.671 \\
High mortality of plant & $2.28^{*}$ & 0.555 \\
Extinction of some insect pollinators and some plants & 1.28 & 0.524 \\
Increased pressure on the biodiversity of the plant & 1.18 & 0.624 \\
Weakening the stem & 1.05 & 0.769 \\
Heat stress reduces fruit setting & 1.03 & 0.003 \\
Increased yield loss & 1.01 & 0.048 \\
\hline
\end{tabular}

${ }^{*}$ Perceived effects of climate change

SD less than 1.0 shows similarity in responses of the respondents

\section{Climate Change Adaptation Strategies and the Level of Effectiveness}

Data in Table 2 show the effectiveness of some of the climate change adaptation strategies used by garden egg producers in the area. The most effective strategies included change of farm sites $(\bar{x}=2.97)$, farming close to irrigated areas $(\bar{x}=2.92)$, establishment of water reserve $(\bar{x}=2.92)$, change of farm activity and practices ( $\bar{x}=$ 2.72), supplementary pesticides, herbicides $(\bar{x}=2.62)$ and avoiding vegetations that harbour pests $(\bar{x}=2.58)$. Meanwhile, change of harvesting methods $(\bar{x}=0.17)$, use of a particular farm $\left(\bar{x}_{=}=0.35\right)$, tree plantation around garden egg farm $\left(\bar{x}_{=}=0.95\right)$ and others with mean less than 1.5 were not effective. The result show that the most effective strategies include change of farm sites close to water sources. In line with the results, Soussain, Burton, \& Hammil (2017) observed that adaptation is necessary to reduce the risks associated with climate change; and reduce the vulnerabilities to climate-induced change in order to protect and enhance the livelihoods of poor people. The standard deviation of the variables were less than one, showing that the individual responses do not vary much from the mean; hence the respondents have similar opinions as regards effectiveness of the adaptation strategies. 
Creative Commons User License: CC BY-NC-ND

Abstracted by: EBSCOhost, Electronic Journals Service (EJS),

Google Scholar, Journal Seek, Scientific Commons,

Food and Agricultural Organization (FAO), CABI and Scopus

http://eoi.citefactor.org/10.11226/v25i4
Journal of Agricultural Extension

Vol. 25 (4) October, 2021

ISSN(e): 24086851; ISSN(Print); 1119944X

http://journal.aesonnigeria.org

http://www.ajol.info/index.php/jae

Email: editorinchief@aesonnigeria.org

\begin{tabular}{lll}
\hline \multicolumn{3}{l}{ Table 2: Level of effectiveness of climate change adaptation strategies used } \\
\hline Adaptation Measures & Mean & Standard Deviation \\
\hline Change of farming sites & $2.97^{*}$ & 0.181 \\
Establishment of water reserve & $2.92^{*}$ & 0.279 \\
Farming garden egg close to irrigated areas & $2.92^{*}$ & 0.279 \\
Change of farm activity and practices & $2.72^{*}$ & 0.454 \\
Amendment of the periods of garden egg operations & $2.67^{*}$ & 0.542 \\
Supplementary pesticide/herbicide use & $2.62^{*}$ & 0.490 \\
Avoiding vegetations that harbour pests & $2.58^{*}$ & 0.497 \\
Protection of farm areas & $1.83^{*}$ & 0.994 \\
Amendment of the periods of harvesting & 1.10 & 0.951 \\
Increase in the number of farms & 1.02 & 0.813 \\
Farming of garden egg under shade of big trees & 1.02 & 0.813 \\
Tree plantation around the garden egg farm & 0.95 & 0.790 \\
Use of a particular farm & 0.35 & 0.486 \\
Change of harvesting method & 0.17 & 0.376 \\
Livelihood diversification & 0.17 & 0.376 \\
Enabling gender-responsive climate information services & 0.14 & 0.420 \\
\hline
\end{tabular}

${ }^{*}$ effective adaptation strategies of climate change. SD less than 1.0 shows similarity in responses

\section{Constraints to Adapting to Climate Change}

Results in Table 3 show that the major constraints faced by garden egg producers are unstable weather $(\bar{x}=3.00)$, unavailability of modern harvesting techniques $(\bar{x}=$ $2.75)$, poor access to materials and equipment $(\bar{x}=2.63)$, high humidity $(\bar{x}=2.62)$, increased pest and disease pathogens $(\overline{\mathrm{x}}=2.68)$, poor infrastructural development $(\overline{\mathrm{x}}$ $=2.55)$. Increasing challenge of theft $(\bar{x}=0.72)$, indiscriminate cutting of trees for firewood $(\bar{x}=0.68)$ and poor knowledge of tree planting practices $(\bar{x}=1.13)$. The standard deviation of the variables were less than one, showing that the individual responses do not vary much from the mean; hence the respondents had similar opinions as regards constraints experienced in adapting to climate change. Unstable weather causes serious devastating damage on garden egg production within short period of time. On further interaction, cultivating when the rainy season is not stable is risky except there is an avenue for irrigation which is labour intensive for commercial producers.

These result is in line with the findings of Iwuchukwu, Arihi, Obazi, Udoye and Ohagwu, 2020) that production of garden egg is constrained by a wide range of pests and diseases, reducing total production as well as production quality. Similarly, Smith and Skinner (2017) reported that women farmers often cite lack of financial resources as a major factor that constrains their use of adaptation measures which entails significant investment. With regards to government efforts at adaptation, Ngigi (2017) posited that lack of government policies on adaptation has remained a serious limitation to effective climate change adaptation in many developing countries and has limited the availability of infrastructure needed to 
Creative Commons User License: CC BY-NC-ND

Abstracted by: EBSCOhost, Electronic Journals Service (EJS),

Google Scholar, Journal Seek, Scientific Commons,

Food and Agricultural Organization (FAO), CABI and Scopus

http://eoi.citefactor.org/10.11226/v25i4
Journal of Agricultural Extension

Vol. 25 (4) October, 2021

ISSN(e): 24086851; ISSN(Print); 1119944X

http://journal.aesonnigeria.org

http://www.ajol.info/index.php/jae

Email: editorinchief@aesonnigeria.org

enhance adaptation. The findings on unavailability of modern harvesting techniques and poor access to materials and equipment as constraints to adaptation to climate change are in line with the work of Bryan, Deressa, Gbetibuou and Ringler (2019) that unstable weather posit as serious constraint to adaptation to climate change in Africa.

There is need to also highlight the major role of government in reducing the constraints being experienced due to poor attention from government. Adequate attention from the government will enhance investments that will bring about provision of infrastructure required to enhance adaptation to the negative consequences of climate change. National Meteorology Centre and National Emergency Management Agency should provide accurate weather information to relevant information disseminating agencies such as the extension service delivery arm of the ADP. This will help in reducing some of the information related constraints experienced by women in adapting to the effects of climate change.

Table 3: Constraints of adapting to climate change by garden egg producers

\begin{tabular}{lll}
\hline Constraints & Mean & $\begin{array}{l}\text { Standard } \\
\text { deviation }\end{array}$ \\
\hline Unstable weather & $3.00^{*}$ & 0.000 \\
Unavailability of modern harvesting techniques & $2.75^{*}$ & 0.437 \\
Increased pest and disease pathogens & $2.68^{*}$ & 0.537 \\
Poor access to materials and equipment & $2.63^{*}$ & 0.551 \\
High humidity & $2.62^{*}$ & 0.490 \\
Inadequate fund for establishment of farms & $2.58^{*}$ & 0.561 \\
Poor infrastructure development & $2.55^{*}$ & 0.675 \\
Inadequate information on adaptation measures & $2.53^{*}$ & 0.623 \\
Increased cost of production & $2.47^{*}$ & 0.747 \\
Time spent on labour & $2.43^{*}$ & 0.745 \\
Excessive wind & $2.27^{*}$ & 0.710 \\
Shortage of skilled man power & $1.95^{*}$ & 0.699 \\
Pesticide threat & $1.87^{*}$ & 0.724 \\
Degradation of natural resources & $1.75^{*}$ & 0.728 \\
Inefficient garden egg farming methods & $1.72^{*}$ & 0.666 \\
Poor knowledge of tree planting practices & 1.13 & 0.911 \\
Increasing challenges of theft & 0.72 & 0.640 \\
Indiscriminate cutting of trees for fire wood & 0.68 & 0.770 \\
\hline
\end{tabular}

${ }^{*}$ Major constraints

SD less than 1.0 shows similarity in responses of the respondents

\section{Conclusion and Recommendations}

Climate change affected garden egg production through scarcity of adequate floral resources, increased spread of pests and pathogens, increased garden egg susceptibility to pathogen, reduced pollen production in flowers and shortening the plant lifespan. Different adaptation strategies were employed by the garden egg 
Creative Commons User License: CC BY-NC-ND

Abstracted by: EBSCOhost, Electronic Journals Service (EJS),

Google Scholar, Journal Seek, Scientific Commons,

Food and Agricultural Organization (FAO), CABI and Scopus

http://eoi.citefactor.org/10.11226/v25i4
Journal of Agricultural Extension

Vol. 25 (4) October, 2021

ISSN(e): 24086851; ISSN(Print); 1119944X

http://journal.aesonnigeria.org

http://www.ajol.info/index.php/iae

Email: editorinchief@aesonnigeria.org

producers to adapt to climate change. Despite the constraints that women experience in accessing information, they made effort to access information on climate change issues from radio, family and friends and fellow farmers. Government ministries (Agriculture, Information, and Environment) should embark on effective campaign on the consequences of climate change, especially in rural areas. Not only will it raise awareness, it will also create in-depth knowledge of human activities that are major contributors to climate change and expose to the women alternative ways of doing things. Provision of effective and reliable access to information on climate change will bring about effective adaptation. There is need to retrain the extension agents on climate change and climate change issues. This will equip extension agents with adequate information on climate change and bring about the dissemination of relevant climate change information. Possession and dissemination of relevant climate change information will influence the sources of information preference of women; thereby making women source information from extension agents frequently.

Due to constraints of unstable weather, telecommunication network providers should work in close association with Meteorology Centre, National Emergency Management Agency, National Environmental Standards regulation Enforcement Agency and climate change unit in the Ministry of Environment to provide regular and timely weather updates as Subject Matter Specialists; this will act as both timely and early warning signal. Women should be assisted to ensure that mal-adaptation does not occur. Extension agents should expose the women to possible diversification strategies such as planting of cover crops.

\section{References}

Arunrat, N., Wang, C., Pumijumnong, N., Sereenonchai, S., \& Cai, W. (2017). Farmer's intention and decision to adapt to climate change: A case study in the Yom anf Nan basins, Phichit province of Thailand. Journal of Cleaner Production, 143, 672-685. https://doi.org/10.1016/j.jclepro.2016.12.058

Bisbis, M.B, Gruda, N and Blanke, M (2018). Potential impacts of climate change on vegetable production and product quality - A review. Journal of Cleaner Production, Volume 170, Pp 1602-1620, ISSN 0959-6526, https://doi.org/10.1016/j.jclepro.2017.09.224.

Bosello, F., Campagnolo, L., Cervigni, R., \& Eboli, F. (2018). Climate Change and Adaptation: The Case of Nigerian Agriculture. Environmental and Resource Economics, 69(4), 787-810. https://doi.org/10.1007/s10640-016-0105-4

Bryan, E., Deressa, T., Gbetibuou, G \& Ringler, C. (2019). Determinants of adaptation to climate change in Ethiopia and South Africa. International Food Policy Research Institute and Center for Environmental Economics and Policy, South Africa

CGIAR. (2021). Recognizing the Agricultural Efforts of Women. 
Creative Commons User License: CC BY-NC-ND

Abstracted by: EBSCOhost, Electronic Journals Service (EJS), Google Scholar, Journal Seek, Scientific Commons,

Food and Agricultural Organization (FAO), CABI and Scopus

http://eoi.citefactor.org/10.11226/v25i4
Journal of Agricultural Extension

Vol. 25 (4) October, 2021

ISSN(e): 24086851; ISSN(Print); 1119944X

http://journal.aesonnigeria.org

http://www.ajol.info/index.php/jae

Email: editorinchief@aesonnigeria.org

https://www.cgiar.org/news-events/news/cgiar-celebrates-international-womensday-2021/

Eze, S. O. (2017). Constraints to climate change adaptation among cassava women farmers: implications for agricultural transformation and food security in Ebonyi State, Nigeria. International Journal Of Ecosystems And Ecology Science-IJEES, 7(2), 219228. https://www.cabdirect.org/cabdirect/abstract/20173327443

Fadairo, O., Williams, P. A., Faridah, S. N \& Nalwanga, S. (2020). Perceived livelihood impacts and adaptation of vegetable farmers to climate variability and change in selected sites from Ghana, Uganda and Nigeria. 22, 6831-6849. https://doi.org/10.1007/s10668-019-00514-1

International Labour Organization (ILO), 2016. Women at work: Trends 2016. International Labour Office, Geneva, Switzerland. [http://www.ilo.org/wcmsp5 /groups/public/_-dgreports/_-dcomm/_-publ/documents/publication/wcms 457317.pdf].

Iwuchukwu J.C, Arihi G.N, Obazi, S.A, Udoye, C.E and Ohagwu, V.A (2020). Knowledge and Adaptation Strategies of Eggplant Farmers to the Effect of Bacterial Wilt Disease in Nsukka Agricultural Zone of Enugu State, Nigeria. Asian Journal of Agricultural Extension, Economics \& Sociology 38(7): 25-33.

Jamin, N., Odoemenam, E. F., \& Godson-Ibeji, C. C. (2019). Indigenous Cognizance Systems of Nigerian Farmers for Climate Change Adaptation and Mitigation in Agriculture. http://jara.org.in

Lawal, A. T., Barau, S. S., \& Umoru, G. I. (2020). Resources Use Efficiency of Garden Egg (salanum melongena) Production in Ringim Local Governmen`t Area of Jigawa State, Nigeria . JCCR / Journal of Community \& Communication Research, 5(1), 184-189. Retrieved from https://iccr.sccdr.org.ng/index.php/iccr/article/view/75

Ngigi, S.N. (2017). Climate change adaptation strategies: Water resources management options for smallholder farming systems in sub-Saharan Africa. A study supported by the Rockefeller Foundation.

Nifeipiri, S. E., Nlerum, C. O., \& Isife. (2020). Assessing women arable crop farmers participation in the development of rural communities of Rivers State, Nigeria. In The International Journal of Agriculture, 4 (2). www.ijamt.com.ng

Nkengla-Asi, L., Babu, S.C., Kirscht, H., Apfelbacher, S., Hanna, R., Tegbaru, A., (2017). Gender, climate change, and resilient food systems: lessons from strategic adaptation by smallholder farmers in Cameroon. International Food Policy Research Institute. Retrieved from. https://cgspace.cgiar.org/handle/10568/83068. 
Creative Commons User License: CC BY-NC-ND

Abstracted by: EBSCOhost, Electronic Journals Service (EJS),

Google Scholar, Journal Seek, Scientific Commons,

Food and Agricultural Organization (FAO), CABI and Scopus

http://eoi.citefactor.org/10.11226/v25i4
Journal of Agricultural Extension

Vol. 25 (4) October, 2021

ISSN(e): 24086851; ISSN(Print); 1119944X

http://journal.aesonnigeria.org

http://www.ajol.info/index.php/jae

Email: editorinchief@aesonnigeria.org

Nnadi, O.I., Liwenga, E.T.. Lyimo, J.G. \& Madukwe M.C (2019). Impacts of variability and change in rainfall on gender of farmers in Anambra, Southeast Nigeria. Heliyon, 5(7), July 2019, e02085

Nyasimi, M., \& Huyer, S. (2017). Closing the gender gap in agriculture under climate change. https://cgspace.cgiar.org/bitstream/handle/10568/81376/Ag4Dev30_6.pdf

Okeke, C.C., Ezeano, C.I., Gbughemobi, B.O., 2016. Effects of rising temperature and wind on productivity of women farmers in Anambra East local government of Anambra state Nigeria. Int. J. Agric. Biosci. 5 (3), 124-127. Retrieved from. https://www.cabdirect.org/cabdirect/abstract/20163196447.

Onyeneke, R.U., \& Madukwe, D.K. (2010). Adaptation measures by crop farmers in the southeast rainforest zone of Nigeria to climate change. Scientific World Journal, 5(1), 32-34.

Palacios-Lopez, A., Christiaensen, L., \& Kilic, T. (2017). How much of the labor in African agriculture is provided by women? Food Policy, 67, 52-63. https://doi.org/10.1016/j.foodpol.2016.09.017

Seo, S.N., \& Mendelsohn, R. (2018). Animal husbandry in Africa: Climate change impacts and adaptations. African Journal ARE., 2(1), pp. 65-82.

Shrestha, R. P., Raut, N., Maung, L., Swe, M., \& Tieng, T. (2018). Climate Change Adaptation Strategies in Agriculture: Cases from Southeast Asia. Sustainable Agriculture Research, 7(3), 39-51. https://doi.org/10.5539/sar.v7n3p39

Smith, B., \& Skinner, M. (2017). Adaptation options in Agriculture to climate change: A typology, mitigation and adaptation strategies for global change. African Journal of Agriculture and Resource Economics 3(5) pp. 78-82.

Soussain, J., Burton, I., \& Hammil, A. (2017). "Livelihoods and climate change: Combining disaster risk reduction, natural resource management and climate change adaptation in a new approach to the reduction of vulnerability and poverty", IUCN/IISD/SEI.

Ugwuja, V. C., \& Nweze, N. J. (2018). Gender analysis of micro-loan sizes accessed by small scale agro-entrepreneurs in the Niger Delta region of Nigeria. Journal of Development and Agricultural Economics, 10(1), 15-21. https://doi.org/10.5897/JDAE2017.0878

Williams, P. A., Crespo, O., \& Abu, M. (2018). Assessing vulnerability of horticultural smallholders' to climate variability in Ghana: Applying the livelihood vulnerability approach. Environment, Development and Sustainability. https://doi.org/10.1007/s10668-018-0292-y.

Wrigley-Asante, C., Owusu, K., Egyir, I. S., \& Owiyo, T. M. (2019). Gender dimensions of 
Creative Commons User License: CC BY-NC-ND

Abstracted by: EBSCOhost, Electronic Journals Service (EJS),

Google Scholar, Journal Seek, Scientific Commons,

Food and Agricultural Organization (FAO), CABI and Scopus

http://eoi.citefactor.org/10.11226/v25i4
Journal of Agricultural Extension

Vol. 25 (4) October, 2021

ISSN(e): 24086851; ISSN(Print); 1119944X

http://journal.aesonnigeria.org

http://www.ajol.info/index.php/jae

Email: editorinchief@aesonnigeria.org

climate change adaptation practices: the experiences of smallholder crop farmers in the transition zone of Ghana. African Geographical Review, 38(2), 126-139. https://doi.org/10.1080/19376812.2017.1340168 